\title{
AUTONOMIA PRIVADA E REGULAÇÃO ESTATAL NA EVOLUÇÃO HISTÓRICA DO ENSINO SUPERIOR BRASILEIRO
}

\author{
PRIVET AUTONOMY AND ESTATE REGULATE IN THE ORIGINS \\ OF THE HIGHER EDUCATION IN BRAZIL
}

\begin{abstract}
AUTONOMÍA PRIVADA Y REGULACIÓN ESTATAL EN LA EVOLUCIÓN HISTÓRICA DE LA ENSEÑANZA SUPERIOR BRASILEÑA
\end{abstract}

Magno Federici GOMES ${ }^{1}$

\begin{abstract}
RESUMO: Objetiva-se, com o presente trabalho, o estudo da expansão da educação superior no Brasil. Este artigo é preponderantemente teórico-documental, por proceder a uma revisão de literatura sobre a expansão da educação superior brasileira, apresentando também suporte empírico do citado fenônemo. Concluiu-se que as políticas educacionais, instituídas com a finalidade de diminuir despesas públicas e ampliar o acesso da população à educação superior, vêm alcançando resultados positivos, apesar de deixar tal nível de ensino submetido a interesses privados.
\end{abstract}

Palavras-chave: políticas públicas educacionais; expansão da educação superior brasileira; dados estatísticos; conseqüências.

ABSTRACT: It is desired, with the present work, the study of the expansion of higher education in Brazil. This one is a preponderantly theoretical-documentary work, to make a revision of literature on the expansion of Brazilian higher education, also presenting empirical support of the mentioned phenomenon. One has concluded that the educational policies, created with the pretension to diminish the expenses public and to extend the access of the population to higher education, are reaching positive results, in spite of putting under such level of education private interests.

Keywords: educational public policies; expansion of Brazilian higher education; statistical data; consequences.

RESUMÉN: Se desea, con el presente trabajo, el estudio de la expansión de la enseñanza superior en Brasil. Se trata de un trabajo preponderantemente teórico-documental, por hacer una revisión de literatura sobre la expansión de la enseñanza superior brasileña, presentando

\footnotetext{
${ }^{1}$ Pós-doutor em Direito Público e Educação pela Universidade Nova de Lisboa-Portugal. Pós-doutor em Direito Civil e Processual Civil, Doutor em Direito e Mestre em Direito Processual, pela Universidad de DeustoEspanha. Mestre em Educação pela PUC Minas. Coordenador do curso de Direito da Faculdade Padre Arnaldo Janssen. Professor do Mestrado Acadêmico em Direito do Centro Universitário UNA. Professor Adjunto da PUC Minas. Advogado Sócio do Escritório Raffaele \& Federici Advocacia Associada.

Endereço eletrônico: federici@pucminas.br
} 
también soporte empírico del citado fenómeno. Se ha concluido que las políticas educacionales, creadas con la pretensión de disminuir los gastos públicos y ampliar el acceso de la población a la enseñanza superior, están alcanzando resultados positivos, a pesar de someter tal nivel de enseñanza a intereses privados.

Palabras-clave: políticas públicas educacionales; expansión de la enseñanza superior brasileña; datos estadísticos; consecuencias.

SUMÁRIO: 1. Introdução - 2. O Fenômeno da Expansão da Educação Superior no Brasil 2.1. A Reforma Universitária de 1968 - 2.2. O Ensino Privado Empresarial - 2.3. O Plano Diretor da Reforma do Aparelho do Estado de 1995 - 3. Dados Estatísticos sobre a Expansão - 4. Considerações Finais - 5. Referências bibliográficas

\section{INTRODUÇÃO}

Objetiva-se, com o presente trabalho, o estudo da expansão da educação superior no Brasil. Desse modo, serão analisadas as políticas públicas, origens, previsões normativas, peculiaridades e consequências do referido fenómeno.

O art. 26.1, da Declaração Universal dos Direitos Humanos, dispõe “[...] o acesso aos estudos superiores deve estar aberto a todos em plena igualdade, em função do seu mérito" (ASSEMBLÉIA GERAL DAS NAÇÕES UNIDAS, 1948).

Da mesma maneira, o art. 208, inciso V, Constituição da República de 1988 (CR/88), pressupõe a capacidade individual, isto é, o mérito de cada pessoa, para assegurar a garantia de acesso ao ensino superior, prévia seleção e classificação perante um número limitado de vagas, o que se diferencia dos níveis fundamental e médio que se destinam a todos, segundo art. 208, incisos I e II, $\mathrm{CR} / 88$.

Em sentido equivalente, a Declaração Mundial sobre Educação Superior no Século XXI: visão e ação, da UNESCO (1998), mostra o ensino superior como sendo o cume do sistema educacional e um serviço público de relevante valor social, pois promove a ação humana a níveis mais elevados. De qualquer forma, a ampliação de acesso ao ensino superior não se mostra tarefa fácil. Sousa (2003) deixa claro ser um paradoxo falar em educação superior desvinculada do sistema social e da educação em geral. Abre-se um parêntesis para ressaltar que:

[...] os direitos mínimos essenciais que consistem em alimentação, vestuário, moradia, saúde, educação e uma renda mínima não possibilitam a aplicação do princípio da progressividade dos direitos sociais. Estes direitos mínimos essenciais são imperativos, independentes e não podem ser escusativas alegações de 
indisponibilidade de recursos ou de qualquer outro fator de dificuldade (JAYME, 2005, p. 176).

Na lição de Sousa (2003), o Brasil é o país da América Latina que possui a mais elevada despesa anual por discente nas Instituições de Ensino Superior (IES) públicas, bem como a menor taxa bruta de escolarização nesse nível de ensino. A mencionada taxa, referente aos cidadãos brasileiros, matriculados na educação superior, é de $13 \%^{2}$, enquanto na Argentina é de $40 \%$, no Uruguai, 30\%, no Chile, 20,6\%, na Venezuela, 26\% e na Bolívia, 20,6\%3․ A Câmara de Educação Superior (CES), do Conselho Nacional de Educação (CNE), emitiu o Parecer $n^{\circ}$ 05, em 07 de junho de 2000, matizando que no âmbito do ensino superior brasileiro:

O primeiro problema a ser enfrentado diz respeito à necessidade de prever a sua ampliação. [...] $\mathrm{O}$ nível industrial e tecnológico do Brasil exige uma expansão acelerada desse nível de

\footnotetext{
2 Sousa (2003) esclarece que "esse percentual refere-se à relação entre o total de matrículas no ensino superior, independentemente da faixa etária dos alunos e o total da população com idade entre 20 e 24 anos. Caso se considere apenas a população dessa faixa etária, o percentual baixa para $7,7 \%$, taxa que se aproxima a uma das mais baixas do mundo". [...] "Visando ampliar esse percentual, o Plano Nacional de Educação, aprovado pela Lei $\mathrm{n}^{\circ}$ 10.172, de 09.01.2001, fixou para os próximos dez anos, a partir de sua publicação, a meta de que, pelo menos, 30\% dos jovens brasileiros com idade regular possam freqüentar uma IES" (SOUSA, 2003 , p. 14, nota 12 ).

${ }^{3}$ Informações extraídas de BRASIL; MEC; SESu, 2000, p. 11. No mesmo sentido, o Plano Nacional de Educação (PNE - Lei $\mathrm{n}^{\circ}$ 10.172/01), quando procede a um diagnóstico da educação superior no Brasil.
}

ensino, especialmente porque o crescimento foi muito reduzido nos últimos quinze anos (BRASIL; MEC; CNE; CES, 2000, p. 444).

Essa expansão se confirma pelo capítulo do ensino superior, no Plano Nacional de Educação (PNE - Lei ${ }^{\circ}$ 10.172/01).

À continuidade dos ensinamentos, Sousa (2003) salienta o distanciamento dos níveis educacionais de brasileiros comparados com os dos países desenvolvidos, como, por exemplo, Estados Unidos com 80\%, França com $50 \%$, Inglaterra com $48 \%$ e Espanha com $46 \%$, de seus cidadãos matriculados no ensino superior. Assim, o autor (2003) afirma que o Brasil precisa aumentar o acesso dos brasileiros, com faixa etária entre 18 e 24 anos, à educação superior e demonstra o consenso com tal objetivo, constante no Parecer CNE/CES n ${ }^{\circ} 293$, de 06 de maio de 1998: “[...] não cabem intenções de conter a expansão da matrícula no ensino superior, antes, cabe promover a ampliação das vagas, desde que com qualidade" (BRASIL; MEC; CNE; CES, 1998, p. 57) ${ }^{4}$.

Em síntese, Ribeiro (2002) destaca que o fenômeno da expansão do sistema educacional superior do Brasil seguiu uma tendência mundial, no pós-guerra. As

\footnotetext{
${ }^{4}$ Para argumentos contrários à ampliação do acesso ao ensino por meio do setor privado, ver MARTINS, 1981, p. 79-116 e 200-202; CUNHA, 1986, p. 119-130.
} 
pressões da sociedade, no sentido da ampliação de acesso ao ensino superior, levaram o seu aumento desenfreado a pontos de massificação. Assim, é necessário aprofundar no referido fenômeno, para que se possa trabalhar a questão da avaliação e do princípio do padrão de qualidade, temas atuais de extrema importância.

Portanto, o fenômeno da expansão do ensino superior no Brasil deve ser melhor estudado e explicitado, para se chegar aos objetivos supramencionados.

Este artigo é preponderantemente teórico-documental, por proceder a uma revisão de literatura sobre a expansão da educação superior brasileira, apresentando também suporte empírico do referido fenônemo, extraído de dados contidos em documentos governamentais emitidos pelo Ministério da Educação (MEC) e pelo Instituto Nacional de Estudos e Pesquisas Educacionais Anísio Teixeira (INEP).

\section{O FENÔMENO DA EXPANSÃO DA EDUCAÇÃO SUPERIOR NO BRASIL}

De maneira que a expansão foi a solução encontrada pelo Poder Público para ampliar o acesso ao ensino superior brasileiro, como se verá mais adiante.

Liberou-se à iniciativa privada os ensinos "primário e secundário no município da corte e o superior em todo
Império" ressalvados problemas de higiene e moralidade, durante a vigência da Constituição de 1824 e do Decreto $\mathrm{n}^{\circ}$ 7.247, de 19 de abril de 1879, Reforma Leôncio de Carvalho, a teor do seu art. $1^{\circ}$. Com a Constituição de 1891, definiu-se, em seu art. 34, inciso XXX, a competência privativa do Congresso Nacional para criação de cursos superiores na Capital da União e, concomitantemente, dos Estados nos seus territórios, em conformidade com os arts. 65,72 , seu $\S 24$ e a falta de proibição legal nesse sentido. Assim, a educação superior particular originou-se na segunda metade do século XIX, porque houve a descentralização do ensino superior, antes mantido apenas pelo Poder Central. Com isso, os Estados também se tornaram responsáveis por tal nível de ensino, autorizando a criação de instituições particulares de educação superior. Como consequiência de tais dispositivos constitucionais, o setor privado inseriu-se no ensino superior por meio de instituições confessionais católicas e de escolas superiores, em determinados estados, ante o desejo de suas respectivas elites. Analisa-se, portanto, a expansão do ensino superior brasileiro, no período de 1808 a 1945, da seguinte forma: $[\ldots]$ até a promulgação da
República, foram fundadas mais 13
escolas de ensino superior,
chegando a 14 o número de
estabelecimentos de ensino
superior. Da Proclamação da 
República até a Revolução de 1930, quando se dá a queda da República Velha, foram criados mais 72 estabelecimentos desse nível, perfazendo, então, o total de 86 . E, finalmente, da Segunda República até 1945, foram criadas mais 95 escolas de nível superior (FÁVERO, 1980, p. $111^{5}$ ).

Durante a República Nova até a redemocratização política do país, mais exatamente entre 1933 e 1960, segundo Sousa (2003), consolidou-se o ensino superior particular no Brasil, tendo em vista a estabilidade e o crescimento do número de matrículas. Em termos gerais:

O ensino superior sofreu intensa expansão quantitativa, concentrada nos últimos quarenta anos. Duas indicações são suficientes para ressaltar o caráter do fenômeno. Primeiro, mais de $81 \%$ dos estabelecimentos de ensino superior, existentes no País em 1960, foram criados entre 1930 e 1960. Segundo, a matrícula geral aumentou, num período de trinta anos, quase seis vezes, passando de 27.501, em 1935, para 155.781, em 1965 (FERNANDES, 1975, p. 65).

Em análise ao referido processo de expansão, Sousa (2003) salienta que:

Tal processo de consolidação aconteceu em um contexto de disputa entre as elites laicas e os grupos hegemônicos católicos que visavam o controle do ensino superior no país. A forma como o segmento privado reagiu às demandas da sociedade fez com que, na primeira metade da década de 30 , este já contasse com cerca de $65,0 \%$ das instituições de ensino superior no Brasil (SOUSA, 2003, p. 15).

As constantes transformações da sociedade brasileira, no período compreendido entre 1940 e 1960, trouxeram novas demandas ao nível educacional superior, que foram devidamente respondidas pelo setor privado, ante uma freqüente ampliação de sua rede de ensino. Ainda para Sousa (2003), a década de 50 configurou o segmento privado em duas fases. $\mathrm{Na}$ primeira fase, $44 \%$ de todas as matrículas inseriam-se na rede privada, cujos cursos visavam à formação de profissionais liberais nas áreas médicas, jurídicas e econômicas. Na segunda fase dos anos 50, exigiu-se uma diversificação dos cursos oferecidos, para garantir a formação de docentes em faculdades de Ciências, Filosofia e Letras, fomentando, ainda, o aparecimento de IES no interior dos Estados membros. Teixeira (1989) interpreta a expansão do ensino superior, no referido momento, considerando:

[...] que a mesma se fez ao correr das circunstâncias, sem plano de previsão, ou mesmo propósito deliberado. Além disso, não decorreu de ato legal determinado, nem refletiu o longo debate educacional que se iniciou na década de 20 e não mais se interrompeu até a votação da Lei de Diretrizes e Bases, em 1961 (TEIXEIRA, 1989, p. 111).

\footnotetext{
${ }^{5}$ Para uma análise detalhada de parte deste período ver CUNHA, 1980, p. 150-159.
} 
a outros interesses dessa mesma natureza que emergiam e buscavam impor-se no âmbito do ensino superior.

Orientada por uma mentalidade assentada no binômio racionalidade e produtividade, a universidade brasileira passava a ser entendida através da relação custo $\mathrm{x}$ benefício, produtividade e o mínimo de investimento [...] (SOUSA, 2003, p. 16-17).

Nesse contexto de obrigatoriedade de racionalização das ações das universidades, publicou-se o Relatório do Grupo de Trabalho da Reforma Universitária (BRASIL; Govêrno Costa e Silva, 1968), cuja atribuição era estudar a realidade do ensino da época, devendo apresentar respostas que viabilizassem a racionalização das atividades universitárias, objetivando maior produtividade e eficiência. Como conclusão principal, o Grupo de Trabalho (GT) indicou a imprescindibilidade de se pensar a educação como elemento de desenvolvimento econômico.

Para Romanelli (2005) e Sousa (2003), o citado GT prosseguia os estudos sobre o contexto da educação brasileira daquele período, anteriormente realizados pela Comissão Meira Matos. Tal Comissão era constituída, segundo Romanelli (2005), pelo seu Presidente, Coronel Carlos Meira Matos, da Escola Superior de Guerra, pelos Professores Hélio de Souza Gomes e Jorge Boaventura de Souza e Silva, pelo Promotor Affonso Carlos Agapito da Veiga e pelo também Coronel-Aviador
Waldir Vasconcelos, do Conselho de Segurança Nacional. A missão desse órgão era, através de inquéritos em escolas superiores, entrevistas com autoridades acadêmicas e representantes estudantis, arrecadar informações sobre as condições gerais da educação superior e as eventuais causas da crise que se previa ${ }^{7}$.

De qualquer forma, Ribeiro (2002) e Sousa (2003) explicam que o GT propunha um modelo universitário desenvolvimentista que, ademais de racional, deveria ser flexível administrativamente:

$$
\begin{aligned}
& \text { [...] a reforma tem objetivos } \\
& \text { práticos e tende a conferir ao } \\
& \text { sistema universitário uma espécie } \\
& \text { de racionalidade instrumental, em } \\
& \text { têrmos de eficiência técnico- } \\
& \text { profissional, que tem por } \\
& \text { conseqüência o aumento de } \\
& \text { produtividade dos sistemas } \\
& \text { econômicos. Para tanto, impõe-se a } \\
& \text { metamorfose de uma instituição } \\
& \text { tradicionalmente acadêmica e } \\
& \text { socialmente seletiva num centro de } \\
& \text { investigação científica e tecnológica } \\
& \text { em condições de assegurar a } \\
& \text { autonomia da expansão industrial } \\
& \text { brasileira (BRASIL; Govêrno Costa } \\
& \text { e Silva, 1968, p. 24-25). }
\end{aligned}
$$

Com isso, a Reforma Universitária, Lei $\mathrm{n}^{\circ} 5.540 / 68$, previa a universidade como a instituição adequada à evolução da educação superior, enquanto as faculdades isoladas seriam as exceções de tal sistema. O Parecer Conselho Federal de Educação

\footnotetext{
${ }^{7}$ Para uma análise detalhada sobre os trabalhos da Comissão Meira Matos e do GT da Reforma
} 113 
(CFE) / Conselho de Ensino Superior (CsEnS) no 209, de 06 de junho de 1967, demonstra as discussões prévias à citada lei, na passagem que se segue:

As escolas isoladas representam uma solução cara, em relação ao número de alunos; precária, quanto aos padrões de ensino; e pouco elástica, quanto às possibilidades de expansão. A boa política parece basear-se na Universidade e na plasticidade dos seus recursos potenciais (BRASIL; MEC; CFE; CsEnS, 1967, p. 21).

Cunha (1988) ressalta a existência de emenda ao projeto de lei que deu origem à Reforma de 1968, de autoria do então Senador Josaphat Marinho, pela qual se excluía a excepcionalidade dos estabelecimentos isolados, ante a falta de recursos para tal intento e a ausência de experiências estrangeiras positivas. Tal emenda foi, segundo Cunha (1988), rejeitada pelo Deputado Lauro Cruz, sem qualquer fundamentação.

Todavia e em conformidade com Tramontin, Braga (1984), Ribeiro (2002) e Sousa (2003), a realidade foi completamente diversa, já que os estabelecimentos isolados aumentaram em níveis extraordinários, o que foi considerado preocupante pelo Poder Público. Assim, a expansão do ensino superior particular, nos últimos trinta anos, divergiu dos princípios norteadores da Reforma Universitária de 1968, pois a mesma se baseava na indissociabilidade entre ensino, pesquisa e extensão. Não obstante e na realidade, o paradigma proposto pela Lei $\mathrm{n}^{\circ} 5.540 / 68$ respondia a interesses acadêmicos de grupos vinculados à pesquisa, apesar de existirem outros setores acadêmicos que se relacionavam com a formação profissional, como, por exemplo, a graduação na educação superior, salientando a luta dentro do campo educacional. De qualquer forma, as políticas públicas educacionais da década de 60 , referentes à educação superior, traziam a finalidade primordial de crescimento da produtividade econômica, bem como de integração social e desenvolvimento de recursos humanos.

Como conseqüência das reformas no ensino superior, introduzidas pelo Governo da época, diversas críticas foram formuladas. Nesse sentido:

[...] Não obstante, conseguiram projetar a reforma universitária nas tendências mais vitais de sua recuperação histórica: o nível técnico e o nível político por vezes entraram em conflito, mas acabaram por se unir no plano mais profundo da reconstrução nacional. Não obtivemos essa possibilidade. A pressão política ultrapassa as soluções técnicas; ou, então, as anula. Quando a pressão política procede das correntes "radicais", ela subestima as soluções técnicas ou revela-se despreparada para formulá-las como uma superação definitiva do existente. Quando a pressão política provém das correntes "conservadoras", ela simplesmente deforma ou esmaga as soluções técnicas. No fundo, a sociedade não encontra, dentro de si mesma, condições para proteger e para incentivar as inovações 
urgentemente necessárias. Em conseqüência, as soluções técnicas emergem antes de deitar raízes nas aspirações comuns dos homens. Elas caem em um vácuo histórico, por falta de base política. Todos lutam pelo poder. Mas o poder em si e para si é tão destrutivo quanto um furacão. Nas mãos dos conservadores, fomenta um reacionarismo estéril, que mantém as soluções técnicas excluídas dos ritmos da história real. No momento em que elas se concretizam, já se acham tão neutralizadas e destorcidas que perdem toda a eficácia. Nas mãos dos seus opositores, representa um mecanismo de pura destruição dos antagonistas. As soluções técnicas ficam à margem da história real, porque se pensa que elas reforçariam o poder conservador. $\mathrm{Na}$ verdade, ignora-se que elas podem desencadear uma espiral de alterações entrelaçadas incontroláveis, lançando o poder conservador no abismo. A reforma universitária foi vítima desse emaranhado de contradições, que evidencia o quanto a sociedade brasileira é pobre de dinamismos políticos socialmente nucleados em interesses coletivos conflitantes, mas bastante fortes para suplantarem os particularismos $\mathrm{e}$ individualismos herdados do período colonial (FERNANDES, 1975, p. 17-18).

Assim, Fernandes (1975) e Minto (2006) acabam por mencionar que a Reforma Universitária foi completamente controlada por forças conservadoras, que retiraram sua índole democrática e inovadora, bem como sua vitalidade política e cultural.

Contudo, a Lei $\mathrm{n}^{\mathrm{o}} \quad 5.540 / 68$ desejava solucionar o dilema de discentes excedentes que pressionavam o governo por novas vagas no ensino superior. $\mathrm{O}$ supramencionado Parecer CFE/CsEnS $n^{\circ}$
209/67 destacava que a educação superior deveria se expandir proporcionalmente aos demais níveis de ensino, respeitando-se sempre o mérito acadêmico individual. Nesse sentido:

\begin{abstract}
O problema dos excedentes decorre, antes de tudo, da ausência duma política cuidadosa e firmemente elaborada [...]. Em muitos (outros) países, entre os quais o nosso, políticos, sociólogos e educadores aceitam que o acesso à educação, em todos os níveis, deve ser franqueado a todos, no limite apenas de suas capacidades e talentos. Êsse (sic) ideal encontra, no entanto, na realidade educacional do País, óbices que cerceiam sua concretização e reduzem, de muito, o que deveria ser um serviço social oferecido a todos (BRASIL; MEC; CFE; CsEnS, 1967, p. 10-11).
\end{abstract}

A Emenda Constitucional (EC) $\mathrm{n}^{\mathrm{o}}$ 1, de 17 de outubro de 1969, que substituiu a Constituição de 1967, em pleno período ditatorial, vinculou $20 \%$ da renda dos impostos municipais ao ensino primário e a suas respectivas redes, sob pena de intervenção. A vinculação para a União e Estados só apareceu pela EC no 24/83, o que demonstrou uma queda na aplicação de receitas na educação escolar durante 16 anos. De maneira que Sousa (2003) ressalta a existência de brechas nas referidas normas constitucionais, pois as mesmas disponibilizaram auxílios técnicos e financeiros do Poder Público ao setor privado, principalmente por meio de bolsas de estudo. Esses benefícios favoreceram a entrada de empresários no campo 
educacional, o que foi visto positivamente pelo Governo de então ${ }^{8}$.

\subsection{O ENSINO PRIVADO EMPRESARIAL}

Durham (1998) e Sousa (2003)

salientam que o segmento privado no ensino superior cresceu e se diversificou nas décadas seguintes à Lei $\mathrm{n}^{\circ}$ 5.540/68, originando um novo tipo de IES, esse último amparado em diretrizes empresariais e mercadológicas. Com isso, alterou-se:

[...] consideravelmente o panorama do ensino superior brasileiro, antes constituído essencialmente pelas instituições públicas e confessionais, este "novo ensino privado" constituiu-se em antítese da real democratização do ensino superior no país (SOUSA, 2003, p. 20).

Em sentido equivalente:

Ao lado de sua característica de empreendimento comandado pela

\footnotetext{
${ }^{8}$ A exemplo do que ocorre nos dias de hoje com o Programa Universidade para Todos (PROUNI), que foi instituído por força da Medida Provisória (MPv) $\mathrm{n}^{\mathbf{0}}$ 213/2004, posteriormente convertida na Lei $\mathrm{n}^{\mathbf{o}}$ 11.096, em 13 de janeiro de 2005. Ademais, a última lei federal foi regulamentada pelo Decreto $\mathrm{n}^{\mathbf{o}}$ 5.493 , de 18 de julho de 2005. Segundo as referidas normas, a gestão do programa cabe ao Ministério da Educação. Sua finalidade é conceder bolsas de estudo integrais e parciais de $50 \%$ (cinquienta por cento) ou de $25 \%$ (vinte e cinco por cento), para discentes "de cursos de graduação e seqüenciais de formação específica, em instituições privadas de ensino superior, com ou sem fins lucrativos" (art. $1^{\circ}$ - Lei $n^{\circ}$ 11.096/05), preenchidos os demais requisitos da lei e do ato administrativo normativo regulador.
}

lógica da acumulação do capital, o "novo" ensino privado representou também uma ruptura na transmissão e produção de um saber crítico, que vinha conquistando um espaço em determinadas áreas do conhecimento, na universidade brasileira (MARTINS, 1989, p. $\left.41^{9}\right)$.

Nos anos 80, Sousa (2003) apresenta a tentativa do Poder Público de, normativa e economicamente, conter o processo de expansão do setor privado, mediante a expedição de vários atos administrativos normativos, todos suspendendo e sustando a criação de cursos de ensino superior em IES, sejam universidades ou não. Entre eles, o Decreto $\mathrm{n}^{\mathrm{o}} 86.000 / 81$, com vigência entre 13 de maio de 1981 a 31 de dezembro de 1982; o Decreto $\mathrm{n}^{\circ}$ 91.694/85, vigendo de 27 de setembro de 1985 a 30 de setembro de 1986; o Decreto $\mathrm{n}^{\text {o }}$ 93.594/86, com aplicação plena entre 19 de novembro de 1986 e 31 de dezembro de 1987; o Decreto $\mathrm{n}^{\mathrm{o}} 95.003 / 87$, que simplesmente estendeu os efeitos do ato normativo anterior até 31 de dezembro de 1988 e foi prorrogado pelo Decreto $n^{\circ} 97.881 / 89$, até 15 de novembro de 1989. Para o mesmo autor (2003), a referida limitação fomentou os questionamentos sobre a qualidade do ensino fornecido pela iniciativa privada naquele período.

\footnotetext{
9 Para aprofundamentos, verificar MARTINS, 1991, p. 63-74.
} 
Além disso e ainda na lição de Sousa (2003), a distribuição espacial das IES privadas nas regiões, na fase da expansão, acarretou um remanejamento do segmento público em locais de baixo interesse para o setor particular. Desse fenômeno da expansão ter sido contínuo após seu início, Sousa (2003) coloca de manifesto que a dinâmica do crescimento do setor privado teve fases de estabilidade e de redução no número de matrículas, tendo em vista o sistema de ensino superior do Brasil, como um todo. De modo que, entre 1980 e 1985, a taxa de crescimento do segmento particular foi negativa. Cabe alertar que o período correto é o compreendido entre 1980 a 1988, pois a rede particular só conseguiu se recuperar a partir de 1989, segundo tabela $n^{\circ} 02$, que logo será analisada.

Com relação às regiões brasileiras, o mesmo autor (2003) explicita a importância do aumento da quantidade de IES privadas, não somente de novos cursos, no Norte e Nordeste, bem como no Centro-Oeste, no período compreendido entre 1985 e 1990. Contudo, no Sul e Sudeste, a expansão da mesma rede ocorreu no interior dos Estados-membros e não em suas capitais. Já entre 1985 e 1996, reduziu-se o número de faculdades isoladas privadas, de 732 para 643, aumentando-se as universidades particulares, de 20 para modo, Durham e Sampaio

(1995)

concluem que, de certa maneira, essa escolha da rede púbica implicou maior acesso ao sistema de ensino.

Apesar

do

$64^{10}$. De maneira que "essa estratégia revelou a intenção do setor privado de criar instituições maiores as quais, oferecendo um leque maior de cursos, passam a ter mais vantagens no processo concorrencial de disputa pela clientela de ensino superior" (SOUSA, 2003, p. 21).

Em continuação dos ensinamentos de Sousa (2003), a busca incessante por alunos exigiu que várias IES particulares criassem unidades em territórios distintos de seus domínios originários, mediante uma atuação, no mercado, semelhante a de grandes empresas. Seguiam, ainda, as referências mercadológicas e preocupavam-se, em certa medida, com a estruturação de suas práticas educativas.

\subsection{O PLANO DIRETOR DA REFORMA DO APARELHO DO ESTADO DE 1995}

Com isso, Sousa (2003) faz uma análise sociológica sobre a educação superior no Brasil e as políticas públicas educacionais:

\footnotetext{
${ }^{10}$ Dados extraídos de BRASIL; MEC; SESu, 2000, p. 12.
} 
$\mathrm{Na}$ análise do campo do ensino superior brasileiro, é importante destacar o seu peso para as políticas públicas, levando o governo Fernando Henrique Cardoso a encará-lo como elemento estratégico para o desenvolvimento nacional. Essa realidade contribui para configurá-lo - talvez mais do que nunca - como objeto de disputa de diversos grupos de atores presentes em um campo marcado pela heterogeneidade das escolas que o compõem (SOUSA, 2003, p. 22).

\section{O governo Fernando Henrique}

Cardoso (FHC) remeteu ao Congresso

Nacional, em 23 de agosto de 1995, durante seu primeiro mandato (1995 a 1998), seu Plano Diretor da Reforma do Aparelho do Estado (BRASIL; PR; CRE, 1995), segundo o qual mostrava o Estado em quatro pontos essenciais: o primeiro, núcleo estratégico e burocrático que concebia a função exclusiva do Estado como propor, definir e exigir o cumprimento das leis, defendendo seu território e estabelecendo relações diplomáticas com outros Estados soberanos. O segundo, os serviços monopolistas de Estado, quando o próprio Estado é o usuário principal de tais serviços estatais, sem qualquer objetivo de lucro. $\mathrm{O}$ terceiro, os serviços sociais competitivos que garantiam a "livre disputa do mercado" e a "eficiência e menor custo dos serviços sociais oferecidos pelas instituições privadas". O quarto, o setor de produção de bens e serviços, formado por empresas públicas que permitiam o acesso irrestrito da população a bens e serviços, cuja pretensão inicial era se transferir totalmente à iniciativa privada, mediante uma venda automática sem controle estatal, por serem atividades empresariais (BRASIL; PR; CRE, 1995, p. 6-11). Desse modo, Sousa (2003) sintetiza que, em virtude de tal Plano Diretor, o governo declarava expressamente que o Estado tinha a finalidade de financiar e coordenar as políticas públicas, não devendo executálas ${ }^{11}$. Deveria, então, delegar a "iniciativa privada a responsabilidade de diminuir as mazelas provocadas pelo mercado" (BRASIL; PR; CRE, 1995, p. 24). Como conseqüência:

Esta posição governamental parece ser interpretada como um estímulo para a entrada de novos atores, instituições e grupos de instituições no ensino superior. Tudo indica que o setor privado sentiu-se convidado a participar da solução de problemas crônicos que rondam este campo, como, por exemplo, o atendimento à demanda por esse nível de ensino no país (SOUSA, 2003, p. 22; em sentido equivalente

\footnotetext{
${ }^{11}$ Baracho (2000), ao analisar a reforma do Estado, sua modernização e privatização, declara que tais temas são acompanhados "de descrições sobre a presença do Estado em matérias econômicas, pelo que é descrito como sobredimensionado. A tendência estatista ou o crescimento da intervenção estatal é uma das características dessa época. O Estado aparece como o mais importante agente econômico, sendo difícil encontrar atividade na qual não intervenha direta ou indiretamente. Algumas bases desse intervencionismo assentam-se em noções de interesse público ou bem comum" (BARACHO, 2000, p. 07).
} 
MINTO, 2006, p. 145-149 e 162164).

Com a vigência plena da LDB atual, Lei ${ }^{\circ}$ 9.394/96, instituiu-se como princípio básico no ordenamento jurídico educacional a autonomia das universidades, já consagrado constitucionalmente. De maneira que, para Sousa (2003), as universidades poderiam criar novos cursos de ensino superior, o que acarretou a expansão do segmento privado de educação superior, pois o setor público não conseguia suprir a procura por este nível de ensino. Ademais, havia ainda a expectativa de lucro derivada de tais ações, mesmo que as IES particulares convivessem com as filantrópicas e comunitárias que, sem fins lucrativos, buscavam propostas de trabalho de índole mais acadêmica. $\mathrm{O}$ mesmo doutrinador (2003) ressalta que, como efeito da demanda e do investimento de certos grupos na educação superior, na década anterior e sob a égide da LDB de 1996, o Brasil vislumbrou novo crescimento acentuado no ensino superior: em 1991, de 1.565.056 matrículas na graduação, 959.320 eram do segmento privado (61\%), enquanto 605.736 eram da rede pública (39\%). Passados 10 anos, as IES públicas tinham 939.225 matrículas $(30,99 \%)$ e as privadas contavam com 2.091.529 matrículas, ou seja, $69,01 \%$ do total.
Por fim, Sousa (2003) analisa o crescimento do segmento particular de ensino superior, ocorrido principalmente do final dos anos 60 até o começo dos 70 e, secundariamente, de 1990 até os dias atuais, como sendo uma resposta ao "cálculo empresarial de custos" e não às demandas da sociedade brasileira, acarretando a "antítese de sua efetiva democratização" (SOUSA, 2003, p. 16). Nesse sentido, Martins (1981) já explicitava que a relação conflituosa entre as IES públicas e privadas, no tocante à rentabilidade financeira, ensejava uma repartição complementar do trabalho intelectual. Portanto:

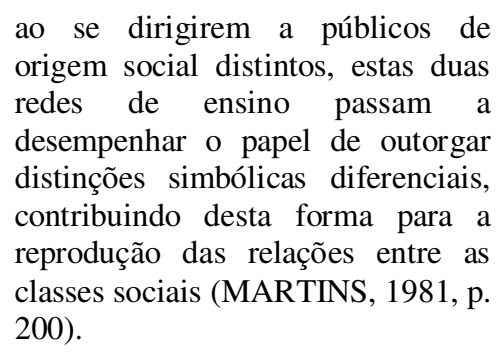
origem social distintos, estas duas redes de ensino passam a desempenhar o papel de outorgar distinções simbólicas diferenciais, contribuindo desta forma para a reprodução das relações entre as classes sociais (MARTINS, 1981, p. 200).

\section{DADOS ESTATÍSTICOS SOBRE A EXPANSÃO}

Para se possa visualizar melhor o fenômeno da expansão no Brasil, passarse-á a apresentar tabelas e gráficos, extraídos dos censos e sinopses estatísticas realizados pelo INEP, relativos ao ensino de graduação.

Destaca-se que a análise terá início em 1980 e terminará em 2006. 
$\mathrm{O}$ ano de início justifica-se pela relação existente entre as redes pública e privada, porque, a partir do mesmo, já cabia "ao setor particular formar a expressiva maioria dos alunos de graduação do sistema" (TRAMONTIN; BRAGA, 1984, p. 22; nesse sentido MARTINS, 1981, p. 199; CURY, 1997, p. 55-56).

A escolha da data término coube à inexistência de dados disponibilizados pelo INEP, após 2006, posto que não se deve utilizar como parâmetro informações cuja credibilidade possa ser colocada em dúvida.

Salienta-se, ainda, que não se pretende analisar as peculiaridades das regiões brasileiras, capital e interior, muito menos os dados referentes aos vestibulares e aos concluintes, pois não é o objeto deste estudo e a referida atribuição exigiria outro enfoque que não o da presente pesquisa.

De maneira que a análise será restrita às informações relativas ao número de IES (natureza e dependência administrativa), matrícula do alunado e quantidade de docentes, na graduação presencial, repita-se, já que a pretensão é apenas estudar o fenômeno da expansão em geral e a relação entre os segmentos público e particular no ensino superior.

Em uma primeira fase, recorre-se à publicação de 1999 do INEP, referente à evolução do ensino superior, no período compreendido entre 1980 e 1998.

Tabela 1: Evolução do Número de Instituições por Natureza e Dependência Administrativa - Brasil (1980-1998)

\begin{tabular}{|c|c|c|c|c|c|c|c|c|c|c|c|c|c|c|c|}
\hline \multirow{2}{*}{ Ano } & \multirow{2}{*}{$\begin{array}{l}\text { Total } \\
\text { Geral } \\
\end{array}$} & \multicolumn{5}{|c|}{ Universidades } & \multicolumn{4}{|c|}{ Fac. Integradas e Centros Universitérios } & \multicolumn{5}{|c|}{ Estabelecimentos /solados } \\
\hline & & Total & Federal & Estadual & Municipal & Privada & Total & Estadual & Municipal & Privada & Total & Federal & Estadual & Municipal & Privada \\
\hline 1980 & 62 & 65 & 34 & 9 & 2 & 20 & 20 & 1 & - & 19 & 797 & 22 & 43 & 89 & 643 \\
\hline 1981 & 876 & 65 & 34 & 9 & 2 & 20 & 49 & 1 & 1 & 47 & 762 & 18 & 68 & 126 & 550 \\
\hline 1982 & 873 & 67 & 35 & 10 & 2 & 20 & 51 & - & 2 & 49 & 755 & 18 & 70 & 122 & 545 \\
\hline 1983 & $\$ 1$ & 67 & 35 & 10 & 2 & 20 & 57 & - & 1 & 56 & 737 & 18 & 69 & 111 & 539 \\
\hline 1984 & 847 & 67 & 35 & 10 & 2 & 20 & 59 & - & 1 & 58 & 721 & 18 & 64 & 108 & 531 \\
\hline 1985 & 65 & 68 & 35 & 11 & 2 & 20 & 59 & - & 1 & 58 & 732 & 18 & 64 & 102 & 548 \\
\hline 1986 & 65 & 76 & 35 & 11 & 3 & 27 & 65 & - & 2 & 63 & 714 & 18 & 79 & 115 & 502 \\
\hline 1987 & 65 & 82 & 35 & 14 & 4 & 29 & 66 & - & - & 66 & 705 & 19 & 69 & 99 & 518 \\
\hline 1988 & 871 & 83 & 35 & 15 & 2 & 31 & 67 & - & 1 & 66 & 721 & 19 & 72 & 89 & 541 \\
\hline 1989 & $\$ 02$ & 93 & 35 & 16 & 3 & 39 & 64 & - & - & 64 & 745 & 19 & 68 & 79 & 579 \\
\hline 1990 & 913 & 95 & 36 & 16 & 3 & 40 & 74 & - & - & 74 & 749 & 19 & 67 & 81 & 582 \\
\hline 1991 & 69 & 99 & 37 & 19 & 3 & 40 & 85 & - & 3 & 82 & 709 & 19 & 63 & 78 & 549 \\
\hline 1992 & 65 & 106 & 37 & 19 & 4 & 46 & 84 & - & 3 & 81 & 703 & 20 & 63 & 81 & 539 \\
\hline 1993 & 873 & 114 & 37 & 20 & 4 & 53 & 88 & - & 3 & 85 & 671 & 20 & 57 & 80 & 514 \\
\hline 1994 & 851 & 127 & 39 & 25 & 4 & 59 & 87 & - & 3 & 84 & 637 & 18 & 48 & 81 & 490 \\
\hline 1995 & 694 & 135 & 39 & 27 & 6 & 63 & 111 & 5 & 5 & 101 & 648 & 18 & 44 & 66 & 520 \\
\hline 1996 & 922 & 136 & 39 & 27 & 6 & 64 & 143 & 4 & 7 & 132 & 643 & 18 & 43 & 67 & 515 \\
\hline 1997 & $\$ 00$ & 150 & 39 & 30 & 8 & 73 & 91 & - & 1 & 90 & 659 & 17 & 44 & 72 & 526 \\
\hline 1998 & 973 & 153 & 39 & 30 & 8 & 76 & 93 & - & - & 93 & 727 & 18 & 44 & 70 & 595 \\
\hline
\end{tabular}

Fonte: BRASIL; MEC; INEP, 1999, p. 13. 
De 1980 a 1998, o ensino superior, em geral, cresceu de 882 para 973 IES, o que significa uma expansão dos setores público e privado, na ordem de 10,32\%, aproximadamente. O gráfico que se segue facilita a visualização da tabela $n^{\circ} 01$, demonstrando a diminuição dos estabelecimentos isolados e o aumento de universidades, centros universitários e faculdades integradas.

Gráfico 1: Distribuição Percentual do Número de Instituições por Natureza - Brasil (19881998)

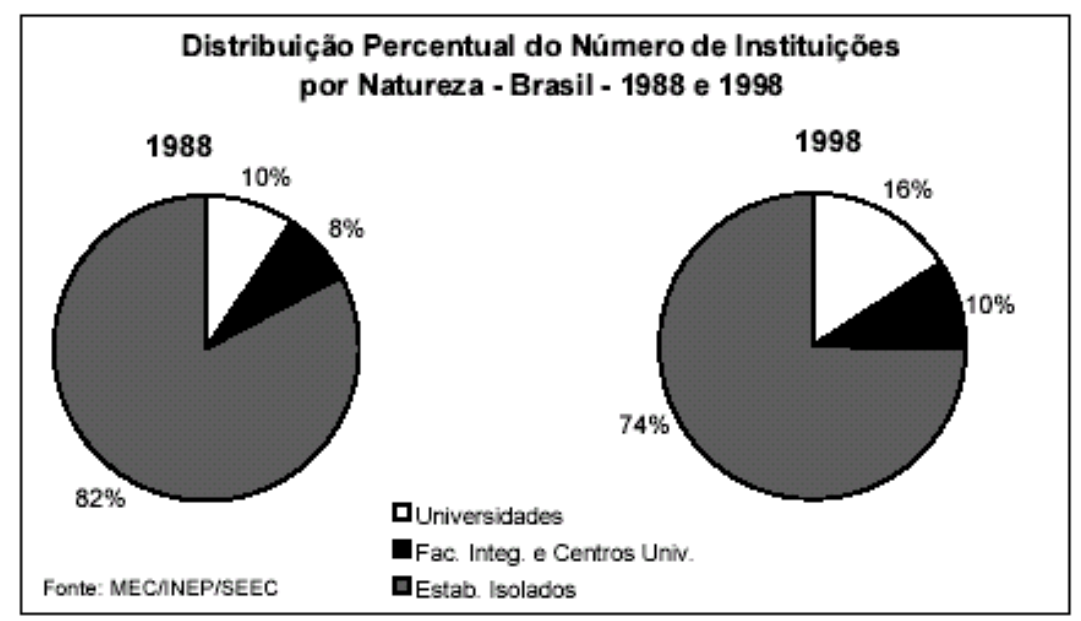

Fonte: BRASIL; MEC; INEP, 1999, p. 13.

Assim, de 1988 a 1998, o gráfico apresenta um crescimento de $6 \%$ nas universidades brasileiras e de $2 \%$ nos centos universitários e faculdades integradas. Por outro lado, demonstra uma redução nos estabelecimentos isolados na ordem de $8 \%$. Pela compatibilidade entre diminuição e crescimento geral de IES de naturezas diferenciadas, nota-se, sem sombras de dúvidas, que essas informações são decorrentes da aglutinação das faculdades isoladas nos outros tipos mais complexos de IES, durante o período estudado.

De qualquer forma, o gráfico $n^{\circ} 01$ serve, também, para se comprovar a heterogeneidade das IES brasileiras, bem como para demonstrar a procedência da crítica sobre "o discurso de sua suposta homogeneidade, pretensamente ideologizado", ou seja, "em um contexto no qual há diferenças de interesses, demandas e organizações internas, o discurso da 'universidade brasileira' é, 
portanto, questionável" (SOUSA, 2003, p. 12). Os referidos dados serviram para dar uma visão de conjunto ao leitor, pois o objetivo principal é trabalhar o tema da dependência administrativa das IES, ou seja, a evolução do número de instituições dos setores público e privado, comparativamente. Para isso:

Tabela 2: $\quad$ Evolução do Número de Instituições por Dependência Administrativa - Brasil (1980-1998)

\begin{tabular}{rrrrrrr}
\hline Ano & Total & Federal & Estadual & Municipal & Privada \\
\hline 1980 & $\mathbf{8 8 2}$ & 56 & 53 & 91 & 682 \\
1981 & $\mathbf{8 7 6}$ & 52 & 78 & 129 & 617 \\
1982 & $\mathbf{8 7 3}$ & 53 & 80 & 126 & 614 \\
1983 & $\mathbf{8 6 1}$ & 53 & 79 & 114 & 615 \\
1984 & $\mathbf{8 4 7}$ & 53 & 74 & 111 & 609 \\
1985 & $\mathbf{8 5 9}$ & 53 & 75 & 105 & 626 \\
1986 & $\mathbf{8 5 5}$ & 53 & 90 & 120 & 592 \\
1987 & $\mathbf{8 5 3}$ & 54 & 83 & 103 & 613 \\
1988 & $\mathbf{8 7 1}$ & 54 & 87 & 92 & 638 \\
1989 & $\mathbf{9 0 2}$ & 54 & 84 & 82 & 682 \\
1990 & $\mathbf{9 1 8}$ & 55 & 83 & 84 & 696 \\
1991 & $\mathbf{8 9 3}$ & 56 & 82 & 84 & 671 \\
1992 & $\mathbf{8 9 3}$ & 57 & 82 & 88 & 666 \\
1993 & $\mathbf{8 7 3}$ & 57 & 77 & 87 & 652 \\
1994 & $\mathbf{8 5 1}$ & 57 & 73 & 88 & 633 \\
1995 & $\mathbf{8 9 4}$ & 57 & 76 & 77 & 684 \\
1996 & $\mathbf{9 2 2}$ & 57 & 74 & 80 & 711 \\
1997 & $\mathbf{9 0 0}$ & 56 & 74 & 81 & 689 \\
1998 & $\mathbf{9 7 3}$ & 57 & 74 & 78 & 764 \\
\hline
\end{tabular}

Fonte: BRASIL; MEC; INEP, 1999, p. 14.

Segundo a tabela $\mathrm{n}^{\circ}$ 02, as IES públicas federais mantiveram seu número quase inalterado, de 56 para 57 (aumento de $1,79 \%$, aproximadamente), o que se justifica pelo fato de, em sua maioria, serem constituídas por universidades. Tiveram uma pequena queda de 1981 a 1989, mas retomaram seu número a partir de 1990. O número das instituições estaduais e municipais oscilou muito. Todavia, mostra-se positivo o crescimento das IES estaduais, de 53 a 74 (aumento de $39,62 \%$, aproximadamente). Contudo, o mesmo não acontece com as municipais que se retraíram consideravelmente, posto que passaram de 91 para 78 (diminuição de $14,29 \%$, aproximadamente).

Da mesma forma que a rede pública estadual, o setor privado também cresceu. Passou de 682 para 764, o que significa um crescimento de, aproximadamente, $12,02 \%$. Dessa forma e fracionadamente, o setor público expandiu $4,5 \%$ e o particular $12,02 \%$. Em níveis gerais, chega-se à conclusão de que o segmento público passou de 200 
instituições para 209, enquanto o privado teve uma progressão de 82 IES. Do crescimento geral do setor educacional superior brasileiro, de 1980 a 1998, calculado em 10,32\% (91 IES), as 09 instituições públicas equivalem a um aumento aproximado de $1,02 \%$ e as 82 instituições particulares comprovam uma expansão de 9,30\%. A criação de estabelecimentos isolados envolve menor investimento do que a de universidades, centros universitários e faculdades integradas, o que pode justificar, em parte, os números apresentados. Entretanto, é público e notório que a iniciativa privada vem investindo, incessantemente, no setor educacional brasileiro. O próximo gráfico apresenta as proporções dos setores público e privado, no campo educacional brasileiro, como um todo:

Gráfico 2: Distribuição Percentual do Número de Instituições por Dependência Administrativa - Brasil (1988-1998)

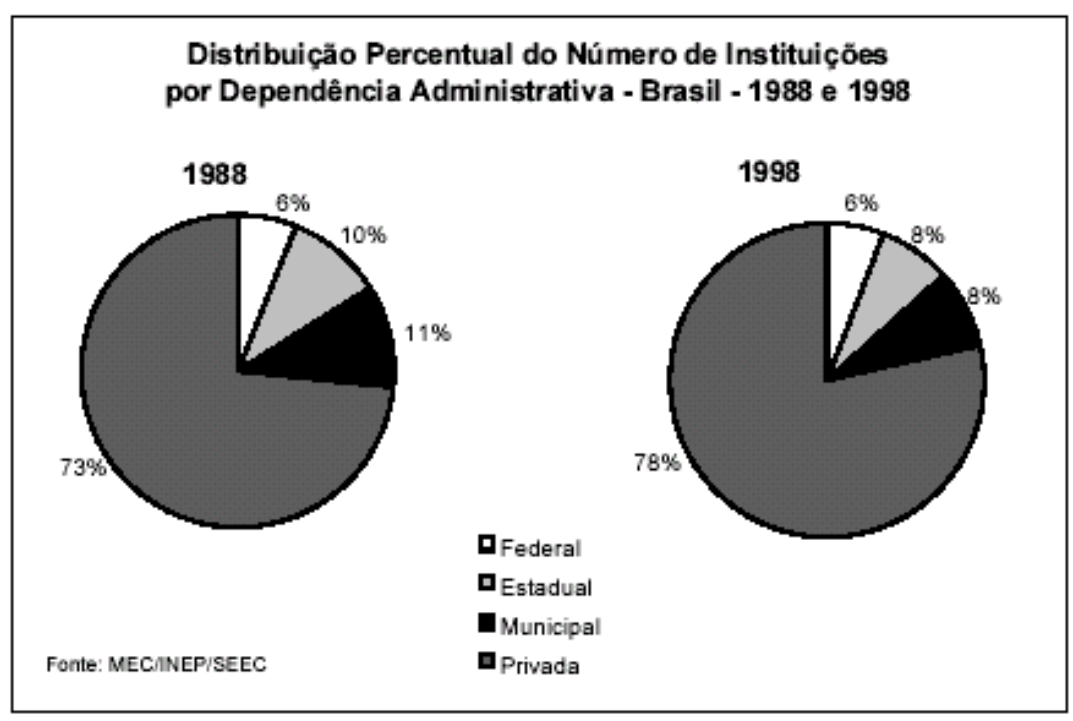

Fonte: BRASIL; MEC; INEP, 1999, p. 14.

Pelo gráfico $n^{\circ} 02$, nota-se que, em 1988, 73,25\% das IES eram particulares, enquanto $26,75 \%$ eram públicas, sendo que $6 \%$ federais, $10 \%$ estaduais e $11 \%$ municipais. O segmento público retraiu-se uma década após, pois, em 1998, 78,50\% das IES eram privadas e os outros $21,50 \%$ eram constituídas por instituições federais (6\%), estaduais (8\%) e municipais (8\%). Assim, a participação do Poder Público no campo da educação superior vem diminuindo, desde então. 
Tabela 3: Evolução da Matrícula por Natureza e Dependência Administrativa - Brasil (1980-1998)

\begin{tabular}{|c|c|c|c|c|c|c|c|c|c|c|c|c|c|c|c|}
\hline \multirow{2}{*}{ Ano } & \multirow{2}{*}{$\begin{array}{l}\text { Total } \\
\text { Geral }\end{array}$} & \multicolumn{5}{|c|}{ Universidades } & \multicolumn{4}{|c|}{ Fac. Integradas e Centros Universitários } & \multicolumn{5}{|c|}{ Estabelecimentos Isolados } \\
\hline & & Total & Federal & Estadual & Municipa & Privada & Total & Estadual & Municipa & Privada & Total & Federal & Estadual & Municipal & Privada \\
\hline 1980 & 1.377 .296 & 652.200 & 305.099 & 81.723 & 17.019 & 248.359 & 96.892 & 2.622 & - & 94.270 & 628.194 & 11.616 & 24.907 & 49.246 & 542.425 \\
\hline 1981 & 1.398 .792 & 644.203 & 301.505 & 82.356 & 17.595 & 242.747 & 186.540 & 2.244 & 5.239 & 179.057 & 556.049 & 11.712 & 45.059 & 70.100 & 429.178 \\
\hline 1982 & 1.407 .987 & 659.500 & 305.468 & 87.499 & 17.624 & 248.909 & 189.146 & - & 7.198 & 181.948 & 559.341 & 11.472 & 47.402 & 71.725 & 428.742 \\
\hline 1983 & 1.438 .992 & 687.860 & 328.044 & 98.371 & 17.213 & 244.232 & 206.408 & - & 5.032 & 201.376 & 544.724 & 12.074 & 48.826 & 67.129 & 416.695 \\
\hline 1984 & 1.399 .539 & 672.624 & 314.194 & 106.066 & 17.602 & 234.762 & 198.818 & $\cdot$ & 4.067 & 194.751 & 528.097 & 12.005 & 49.947 & 67.998 & 398.147 \\
\hline 1985 & 1.357 .609 & 671.977 & 314.102 & 104.441 & 15.414 & 238.020 & 184.016 & - & 4.052 & 179.964 & 511.616 & 12.420 & 42.375 & 63.876 & 392.945 \\
\hline 1986 & 1.418 .196 & 722.863 & 313.520 & 104.816 & 20.600 & 283.927 & 190.711 & - & 3.094 & 187.617 & 504.622 & 12.214 & 48.973 & 74.415 & 369.020 \\
\hline 1987 & 1.470 .555 & 761.236 & 315.956 & 114.418 & 26.180 & 304.682 & 197.810 & - & - & 197.810 & 511.509 & 13.467 & 53.621 & 61.323 & 383.098 \\
\hline 1988 & 1.503 .560 & 770.240 & 304.465 & 129.785 & 17.178 & 318.812 & 201.744 & - & 965 & 200.779 & 531.576 & 13.366 & 60.951 & 58.641 & 398.618 \\
\hline 1989 & 1.518 .904 & 816.024 & 301.535 & 136.137 & 21.663 & 356.689 & 183.483 & $\cdot$ & $\cdot$ & 183.483 & 519.397 & 13.748 & 57.560 & 53.771 & 394.318 \\
\hline 1990 & 1.540 .090 & 824.627 & 294.626 & 136.257 & 23.499 & 370.245 & 202.079 & - & - & 202.079 & 513.374 & 14.241 & 58.160 & 51.842 & 389.131 \\
\hline 1991 & 1.585 .058 & 855.258 & 305.350 & 153.678 & 24.390 & 371.840 & 225.700 & - & 9.266 & 216.434 & 484.098 & 14.785 & 48.637 & 49.630 & 371.046 \\
\hline 1992 & $1.5 \times 5.798$ & 871.729 & 310.533 & 159.963 & 30.353 & 370.880 & 205.465 & - & 9.445 & 196.020 & 458.594 & 15.351 & 50.170 & 53.847 & 339.226 \\
\hline 1993 & 1.594 .669 & 940.921 & 328.907 & 167.674 & 28.623 & 415.717 & 210.117 & - & 10.362 & 199.755 & 443.630 & 15.480 & 48.861 & 53.609 & 325.680 \\
\hline 1994 & 1.6891 .034 & 1.034 .726 & 349.790 & 190.271 & 31.547 & 463.118 & 203.471 & - & 10.344 & 193.127 & 422.837 & 13.753 & 41.665 & 53.080 & 314.339 \\
\hline 1995 & 1.799 .703 & 1.127 .932 & 353.235 & 201.974 & 43.370 & 529.353 & 193.814 & 1.161 & 4.168 & 188.485 & 437.957 & 14.296 & 36.080 & 46.256 & 341.325 \\
\hline 1996 & 1.9888 .529 & 1.209 .400 & 373.880 & 204.819 & 47.432 & 583.269 & 245.029 & 1.592 & 7.089 & 236.348 & 414.100 & 15.107 & 36.690 & 48.818 & 313.485 \\
\hline 1997 & 1.945 .615 & 1.326 .459 & 380.980 & 226.149 & 59.292 & 660.038 & 192.667 & - & 1.078 & 191.589 & 426.489 & 14.853 & 27.529 & 49.301 & 334.806 \\
\hline 1998 & 2.125 .958 & 1.467 .888 & 392.873 & 239.908 & 67.758 & 767.349 & 216.137 & - & - & 216.137 & 441.933 & 15.767 & 35.026 & 53.397 & 337.743 \\
\hline
\end{tabular}

Fonte: BRASIL; MEC; INEP, 1999, p. 19.

Pela mesma, nota-se que as matrículas aumentaram de 1.377.286, em 1980, para 2.125.958, em 1998. Desse modo, houve um aumento significativo de $54,36 \%$ no número de alunos matriculados nas IES.

Tabela 4: Evolução da Matrícula por Dependência Administrativa - Brasil (1980-1998)

\begin{tabular}{|c|c|c|c|c|c|}
\hline Ano & Total & Federal & Eetadual & Municipal & Privada \\
\hline 1960 & 1.377 .286 & 316.715 & 109.252 & 66.265 & 885.064 \\
\hline 1981 & 1.396 .792 & 313.217 & 129.659 & 92.994 & 850.892 \\
\hline 1962 & 1.407.987 & 316.940 & 134.901 & 96.547 & 859.599 \\
\hline 1963 & 1.438 .992 & 340.118 & 147.197 & 89.374 & 862.303 \\
\hline 1984 & 1.399 .539 & 326.199 & 156.013 & 89.667 & 827.680 \\
\hline 1965 & 1.387 .609 & 326.522 & 146.816 & 83.342 & 810.929 \\
\hline 1966 & 1.418 .196 & 325.734 & 153.799 & 90.109 & 840.564 \\
\hline 1967 & 1.470 .555 & 329.423 & 168.099 & 87.503 & 865.590 \\
\hline 1968 & 1.503 .560 & 317.831 & 190.736 & 76.784 & 918.209 \\
\hline 1969 & 1.518 .904 & 316.283 & 193.697 & 75.434 & 934.490 \\
\hline 1990 & 1.540 .000 & 308.067 & 194.417 & 75.341 & 961.455 \\
\hline 1991 & 1.565 .056 & 320.135 & 202.315 & 83.296 & 959.320 \\
\hline 1992 & 1.535 .788 & 325.834 & 210.133 & 93.645 & 906.126 \\
\hline 1993 & 1. 594.668 & 344.387 & 216.535 & 92.594 & 941.162 \\
\hline 1994 & 1.661 .034 & 363.543 & 231.996 & 94.971 & 970.584 \\
\hline 1996 & 1.759 .703 & 367.531 & 239.215 & 99.794 & 1.059 .163 \\
\hline 1996 & 1.868 .529 & 369.967 & 243.101 & 103.339 & 1.133 .102 \\
\hline 1997 & 1.945 .615 & 396.833 & 253.678 & 109.671 & 1.186 .433 \\
\hline 1998 & 2. 125.958 & 408.640 & 274.934 & 121.165 & 1.321 .229 \\
\hline BQVS (\%) & 41,4 & 28,8 & 44,1 & 57,8 & 43,9 \\
\hline
\end{tabular}

Fonte: BRASIL; MEC; INEP, 1999, p. 20. 
A última tabela leva em consideração o período entre 1988 e 1998 , segundo o qual houve um aumento de $28,6 \%$ das matrículas nas instituições federais, $44,1 \%$ nas estaduais, $57,8 \%$ nas municipais e 43,9\% nas particulares. Em números globais, as matrículas nos cursos superiores cresceram na ordem de $41,4 \%$, representativo de 622.398 alunos. Da citada porcentagem, 90.809 matrículas cabem às federais, que indicam $6,04 \%$ do crescimento geral. No âmbito estadual, 84.198 matrículas, que importa em uma fatia de 5,6\% da expansão do sistema. Quanto às matrículas municipais, 44.371 que demonstram a responsabilidade por
$2,95 \%$ do todo. $\mathrm{Na}$ rede privada, o acréscimo de matrículas foi no patamar de 403.020, ou seja, $26,81 \%$ da expansão total das mesmas no sistema educacional do país. Assim, está claro que tanto a rede pública quanto a privada aumentaram o número de matrículas aos alunos resultantes do ensino médio. Contudo, o setor público, nas esferas federal, estadual e municipal, responsabilizou-se por apenas $14,59 \%$ desse crescimento.

Como manifestação explícita da última tabela, apresenta-se o gráfico que demonstra a totalidade das matrículas nos anos de 1988 e 1998, como se pode ver:

Gráfico 3: Distribuição Percentual da Matrícula por Dependência Administrativa - Brasil (1988-1998)

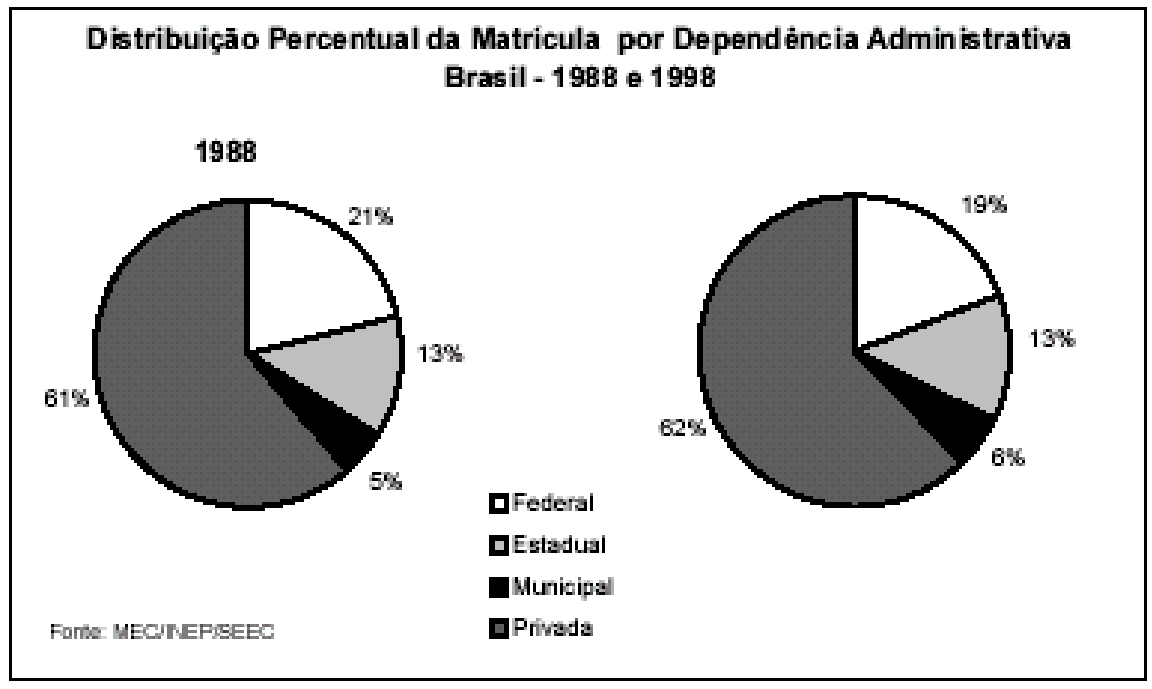

Fonte: BRASIL; MEC; INEP, 1999, p. 20. 
Nota-se, pelo gráfico $\mathrm{n}^{\circ} 03$, que a participação das IES públicas estaduais continuou exatamente igual no período de 10 anos acima indicado. Com referência às federais, a porcentagem de suas matrículas, na totalidade do sistema, teve uma redução de $2 \%$, pois passou de $21 \%$ para $19 \%$. Essa perda foi absorvida pelas instituições públicas municipais e pelas particulares, porque cada uma assimilou 1\%. Está claro, pela tabela $\mathrm{n}^{\circ}$ 04, que todas as IES aumentaram suas matrículas, mas não na proporção que costumavam oferecer.

Outro elemento que pode fornecer subsídios ao fenômeno da expansão do ensino superior e à relação entre as redes públicas e privadas é o número de funções docentes nas IES, devidamente classificadas por suas dependências administrativas. Dessa forma:

Tabela 5: Evolução do Número de Funções Docentes em Exercício por Dependência Administrativa - Brasil (1980-1998)

\begin{tabular}{|c|c|c|c|c|c|}
\hline Ano & Total & Federal & Estadual & Municipal & \begin{tabular}{|l} 
Privada \\
\end{tabular} \\
\hline 1980 & 109.788 & 42.010 & 14.141 & 4.186 & 49.451 \\
\hline 1981 & 113.899 & 43.734 & 15.462 & 5.723 & 48.980 \\
\hline 1982 & 116.111 & 43.866 & 16.566 & 6.015 & 49.664 \\
\hline 1983 & 113.779 & 42.974 & 16.334 & 5.496 & 48.975 \\
\hline 1984 & 113.844 & 41.818 & 17.407 & 5.020 & 49.599 \\
\hline 1985 & 113.459 & 42.087 & 17.392 & 4.970 & 49.010 \\
\hline 1986 & 117.211 & 42.768 & 19.099 & 5.378 & 49.966 \\
\hline 1987 & 121.228 & 44.179 & 20.330 & 4.847 & 51.872 \\
\hline 1988 & 125.412 & 44.548 & 21.732 & 4.109 & 55.023 \\
\hline 1989 & 128.029 & 43.397 & 22.556 & 4.142 & 57.934 \\
\hline $\begin{array}{l}1990 \\
1991\end{array}$ & $\begin{array}{l}131.641 \\
133.135\end{array}$ & $\begin{array}{l}44.344 \\
43.404\end{array}$ & $\begin{array}{l}23.224 \\
23.784\end{array}$ & $\begin{array}{l}4.336 \\
4.935\end{array}$ & $\begin{array}{l}59.737 \\
61.012\end{array}$ \\
\hline 1992 & 134.403 & 41.564 & 24.554 & 6.124 & 62.161 \\
\hline 1993 & 137.156 & 42.304 & 23.963 & 6.327 & 64.562 \\
\hline 1994 & 141.482 & 43.556 & 25.239 & 6.490 & 66.197 \\
\hline 1995 & 145.290 & 44.486 & 25.932 & 5.850 & 69.022 \\
\hline 1996 & 148.320 & 42.110 & 26.064 & 6.492 & 73.654 \\
\hline 1997 & 165.964 & 50.059 & 27.714 & 6.818 & 81.373 \\
\hline 1998 & 165.122 & 45.611 & 30.621 & 7.506 & 81.384 \\
\hline $88 / 98(\%)$ & 31,7 & 2,4 & 40,9 & 82,7 & 47,9 \\
\hline
\end{tabular}

Fonte: BRASIL; MEC; INEP, 1999, p. 36.

Coloca-se de manifesto que tais dados excluíram os docentes afastados das
IES, tendo em vista a metodologia utilizada pelo INEP no trabalho 126 
relacionado com o ensino superior, entre 1980 e 1998. De qualquer maneira, essa tabela também analisa o período de 1988 e 1998, agora com relação ao número de funções docentes, exercidas nas IES. Houve um aumento de 2,4\% de professores em exercício nas instituições federais, $40,9 \%$ nas estaduais, $82,7 \%$ nas municipais e $47,9 \%$ nas particulares. Em números globais, os cargos docentes nos cursos superiores de graduação cresceram na ordem de $31,7 \%$, representativo de 39.710 funções. Da citada porcentagem, 1.063 cargos couberam às federais, que indicam $0,85 \%$ do crescimento geral. No âmbito estadual, aumento de 8.889 funções, que importam em uma fatia de 7,10\% da expansão do sistema. Quanto aos docentes municipais, 3.397 que demonstram a responsabilidade por $2,71 \%$ do todo. $\mathrm{Na}$ rede privada, o acréscimo de cargos de professores girou em torno de 26.361, ou seja, 21,04\% da expansão total dos mesmos no sistema educacional do país. Novamente, demonstra-se que tanto a rede pública quanto a privada aumentaram o número de funções docentes em exercício no país. Contudo, o setor público, nas esferas federal, estadual e municipal, responsabilizou-se por somente $10,66 \%$ desse crescimento.

Ao se comparar o número de matrículas com a quantidade de funções docentes no setor público, verifica-se que as matrículas cresceram na ordem de $14,59 \%$, enquanto o professorado em $10,66 \%$ (diferença de 3,93 pontos). Tais informações podem trazer duas hipóteses, que merecem um estudo mais aprofundado para se constatar qual delas é a verdadeira. A primeira, pode ter havido uma sobrecarga nos recursos humanos das instituições públicas, em virtude do acréscimo superior do número de matrículas. A segunda, em alternância, o quadro docente das instituições públicas estava acima das necessidades institucionais, não ensejando problemas aos professores o aumento das matrículas no ensino superior.

Se forem analisados, também comparativamente, o crescimento do número de matrículas e o aumento nas funções docentes, ambos inerentes à rede particular, no período de 1988 a 1998, pode-se chegar aos seguintes dados: - O acréscimo de matrículas foi no patamar de 403.020, ou seja, 26,81\% da expansão total das mesmas no sistema educacional do país. - Na rede privada, o acréscimo de cargos administrativos de professores girou em torno de 26.361, ou seja, 21,04\% da expansão total dos mesmos no sistema educacional do país. A diferença entre os dados é de 5,77 pontos, o que pode demonstrar piores condições laborais no segmento particular. De qualquer maneira, 
este ponto não é o objeto do trabalho, mas merece uma futura investigação.

Em ambos os casos, segmentos público e privado, a expansão dos cargos docentes não acompanhou o aumento da matrícula, o que, sem qualquer dúvida, significa um aumento na demanda pelo ensino superior.

Assim e como explicação da tabela $\mathrm{n}^{\circ} 05$, apresenta-se o gráfico que ilustra o aumento das funções docentes no período de 1988 a 1998:

Gráfico 4: Distribuição Percentual do Número de Funções Docentes por Dependência Administrativa - Brasil (1988-1998)

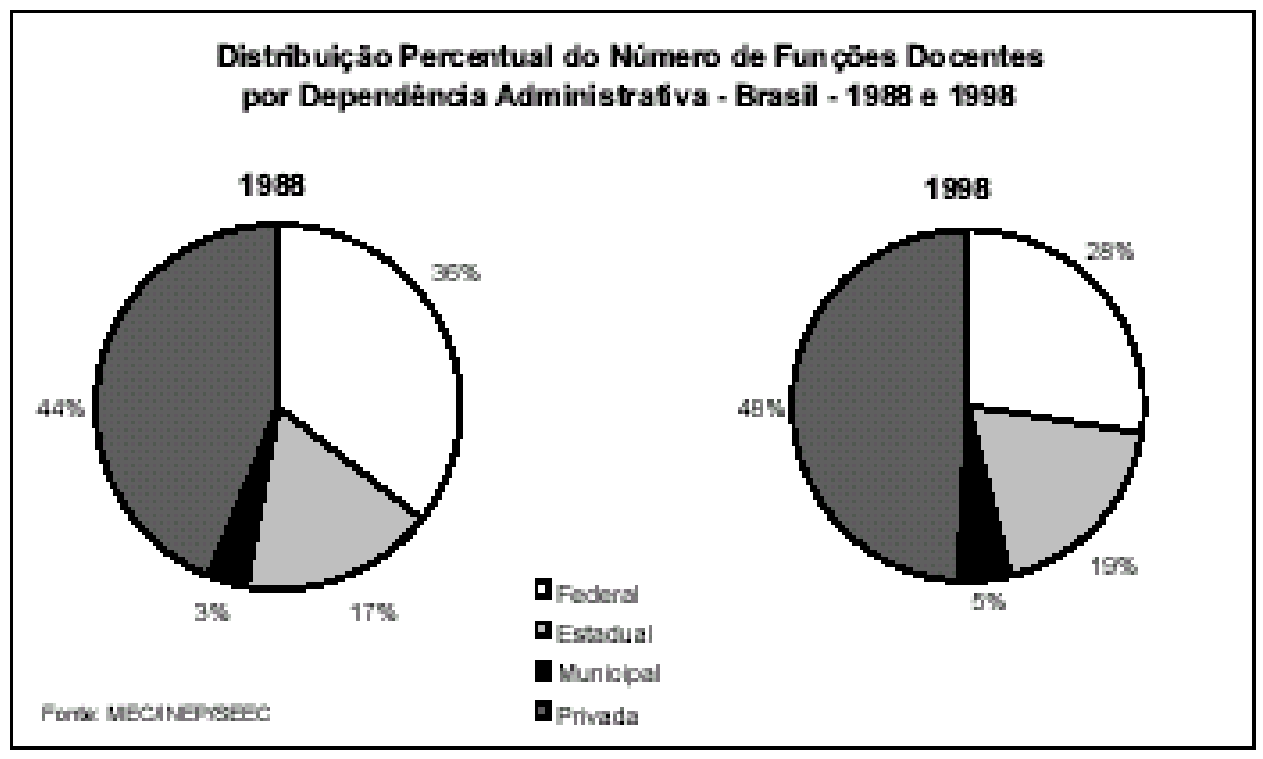

Fonte: BRASIL; MEC; INEP, 1999, p. 36.

O gráfico $\mathrm{n}^{\mathrm{o}} \quad 04$ apresenta $\mathrm{o}$ comentário supra-indicado, já que houve uma redução no professorado das Instituições Federais de Ensino Superior (IFES), na ordem de $8 \%$ (de $36 \%$ para $28 \%$ ) do quadro total de docentes no Brasil. Em todos os outros tipos de IES, sejam públicas (estaduais ou municipais) ou particulares, houve algum tipo de crescimento nos seus recursos humanos. As estaduais 2\% (de 17\% para 19\%), as municipais $2 \%$ (de $3 \%$ para $5 \%$ ) e as privadas $4 \%$ (de $44 \%$ para $48 \%$ ), do número global de funções de professores. Cabe ressaltar que o segmento particular empregava $48 \%$ dos docentes em 1998, aumentando sua fatia que era de $44 \%$ em 1988. Isso demonstra a expansão superior da rede privada em relação à pública.

Agora, em uma segunda fase, farse-á uma tabulação mais simplificada de informações extraídas das sinopses 
estatísticas, realizadas pelo INEP, no período de 1999 a 2006.

Da mesma forma que a primeira fase desta parte, analisar-se-á o número de IES, de matrículas e de funções docentes, levando-se em consideração a dependência administrativa, de maneira que seja possível fazer o paralelo entre os setores público e privado, desenhando o fenômeno da expansão do ensino superior no país.

Tabela 6: Evolução do Número de Instituições por Dependência Administrativa - Brasil (1999-2006)

\begin{tabular}{|c|c|c|c|c|c|}
\hline Ano & Total & IES Públicas & \% & IES Privadas & \% \\
\hline 1999 & 1097 & 192 & 17,5 & 905 & 82,5 \\
\hline 2000 & 1180 & 176 & 14,9 & 1004 & 85,1 \\
\hline 2001 & 1391 & 183 & 13,2 & 1208 & 86,8 \\
\hline 2002 & 1637 & 195 & 11,9 & 1442 & 88,1 \\
\hline 2003 & 1859 & 207 & 11,1 & 1652 & 88,9 \\
\hline 2004 & 2013 & 224 & 11,13 & 1789 & 88,87 \\
\hline 2005 & 2165 & 231 & 10,67 & 1934 & 89,33 \\
\hline 2006 & 2270 & 248 & 10,93 & 2022 & 89,07 \\
\hline
\end{tabular}

Fonte: BRASIL; MEC; INEP, 2000, 2001, 2002, 2003, 2004, 2005, 2006 e 2007.

A tabela $\mathrm{n}^{\circ} 06$ apresenta o número total de IES no país, seguido do número de instituições públicas e privadas, bem como suas porcentagens sobre a quantidade geral. Destaca-se a expansão de IES em 1.173 instituições (crescimento real de $106,93 \%)$, pois de 1.097 passaram para 2.270, no período de 1999 a 2006. Desse crescimento, as IES públicas aumentaram seu número em 56, representativas de $5,11 \%$ do crescimento geral, enquanto as privadas acresceram seu todo em 1.117 instituições, ficando com $101,82 \%$ da expansão total do setor educacional.

Dessa forma e em continuidade com os dados apresentados pelo INEP, na primeira fase desta parte, aqui, também, mostra-se uma expansão de ambos os setores. Contudo, nota-se que a rede pública, com o passar dos anos, ocupou menor espaço na educação superior em geral. Em 1999, mantinha 17,5\% de todo o ensino superior. Esse nível foi se retraindo, ano após ano, até chegar a 10,93\%, em 2006. Assim, o espaço cedido pelo setor 
público foi prontamente ocupado pela rede particular que, em 1999, possuía 82,5\% de todas as IES no Brasil, para, em 2006, passar a deter $89,07 \%$. As exceções à referida afirmação foram os anos de 2003 para 2004 e 2005 para 2006, pois as IES públicas recuperaram $0,03 \%$ e $0,26 \%$, respectivamente, da educação superior, em detrimento do segmento privado.

A cessão de espaço do setor público para o particular será uma constante em todas as tabelas que se seguirão.

Tabela 7: Evolução da Matrícula por Dependência Administrativa, em cursos presenciais - Brasil (1999-2006)

\begin{tabular}{|c|c|c|c|c|c|c|c|c|}
\hline Ano & $\begin{array}{c}\text { Total } \\
\text { IES }\end{array}$ & $\begin{array}{c}\text { Total de } \\
\text { Matrículas }\end{array}$ & $\begin{array}{c}\text { IES } \\
\text { Públicas }\end{array}$ & $\begin{array}{c}\text { Matrículas } \\
\text { Públicas }\end{array}$ & $\begin{array}{c}\text { \% Matrí. } \\
\text { Públicas }\end{array}$ & $\begin{array}{c}\text { IES } \\
\text { Privadas }\end{array}$ & $\begin{array}{c}\text { Matrículas } \\
\text { Privadas }\end{array}$ & $\begin{array}{c}\text { \% Matrí. } \\
\text { Privadas }\end{array}$ \\
\hline 1999 & 1097 & 2369945 & 192 & 832022 & 35,11 & 905 & 1537923 & 64,89 \\
\hline 2000 & 1180 & 2694245 & 176 & 887026 & 32,92 & 1004 & 1807219 & 67,08 \\
\hline 2001 & 1391 & 3030754 & 183 & 939225 & 30,99 & 1208 & 2091529 & 69,01 \\
\hline 2002 & 1637 & 3479913 & 195 & 1051655 & 30,22 & 1442 & 2428258 & 69,78 \\
\hline 2003 & 1859 & 3887022 & 207 & 1136370 & 29,23 & 1652 & 2750652 & 70,77 \\
\hline 2004 & 2013 & 4163733 & 224 & 1178328 & 28,30 & 1789 & 2985405 & 71,70 \\
\hline 2005 & 2165 & 4453156 & 231 & 1192189 & 26,77 & 1934 & 3260967 & 73,23 \\
\hline 2006 & 2270 & 4676646 & 248 & 1209304 & 25,86 & 2022 & 3467342 & 74,14 \\
\hline
\end{tabular}

Fonte: BRASIL; MEC; INEP, 2000, 2001, 2002, 2003, 2004, 2005, 2006 e 2007.

Com relação às matrículas no ensino superior, as mesmas aumentaram, em todos os anos analisados, tanto no segmento público quanto no privado. Passaram de 2.369.945 matrículas em 1999, para 4.676.646 em 2006. Com isso, aumentaram as matrículas em 2.306.701, indicativas de uma expansão de 97,33\%. A proporção cabível do crescimento total de matrículas ao ensino superior público foi de $377.282(15,92 \%)$ e ao privado foi de $1.929 .419(81,41 \%)$.
De maneira que a ampliação do acesso ao ensino superior vem sendo uma responsabilidade das IES particulares, em conformidade com os dados apresentados. Tal afirmativa estava no plano teórico quando se apresentou a intenção do Poder Público (Governo e MEC), manifestada nos Pareceres CNE/CES n 293, de 06 de maio de 1998, e nº 05, de 07 de junho de 2000, de se ampliar o acesso da população à educação superior. Agora, as informações relativas às matrículas não 
deixam quaisquer dúvidas na efetivação das políticas públicas educacionais, planejadas desde 1998.

A evolução no quadro de docentes das IES serve, simplesmente, para respaldar o aumento do número de instituições. Houve um aumento geral de 143.046 docentes no período compreendido entre 1999 e 2006, que demonstra um crescimento de $82,29 \%$ de professores no ensino superior. Da referida expansão de recursos humanos, $15,02 \%$ couberam ao setor público, com um aumento de 26.116 docentes. No que toca à rede privada, as funções do professorado cresceu na ordem de 116.930, representativa de $67,27 \%$ da expansão total.

Tabela 8: Evolução do Número de Funções Docentes em Exercício e Afastados por Dependência Administrativa - Brasil (1999-2006)

\begin{tabular}{|c|c|c|c|c|c|c|c|c|}
\hline Ano & Total IES & $\begin{array}{c}\text { Total de } \\
\text { Funções } \\
\text { Docentes }\end{array}$ & $\begin{array}{c}\text { IES } \\
\text { Públicas }\end{array}$ & $\begin{array}{c}\text { Docentes } \\
\text { em IES } \\
\text { Públicas }\end{array}$ & $\begin{array}{c}\text { \% Doce. } \\
\text { em IES } \\
\text { Públicas }\end{array}$ & $\begin{array}{c}\text { IES } \\
\text { Privadas }\end{array}$ & $\begin{array}{c}\text { Docentes } \\
\text { em IES } \\
\text { Privadas }\end{array}$ & $\begin{array}{c}\text { \% Doce. } \\
\text { em IES } \\
\text { Privadas }\end{array}$ \\
\hline 1999 & 1097 & 173836 & 192 & 80883 & 46,53 & 905 & 92953 & 53,47 \\
\hline 2000 & 1180 & 197712 & 176 & 88154 & 44,59 & 1004 & 109558 & 55,41 \\
\hline 2001 & 1391 & 219947 & 183 & 90950 & 41,35 & 1208 & 128997 & 58,65 \\
\hline 2002 & 1637 & 242475 & 195 & 92215 & 38,03 & 1442 & 150260 & 61,97 \\
\hline 2003 & 1859 & 268816 & 207 & 95863 & 35,66 & 1652 & 172953 & 64,34 \\
\hline 2004 & 2013 & 293242 & 224 & 100424 & 34,25 & 1789 & 192818 & 65,75 \\
\hline 2005 & 2165 & 305960 & 231 & 104119 & 34,03 & 1934 & 201841 & 65,97 \\
\hline 2006 & 2270 & 316882 & 248 & 106999 & 33,77 & 2022 & 209883 & 66,23 \\
\hline
\end{tabular}

Fonte: BRASIL; MEC; INEP, 2000, 2001, 2002, 2003, 2004, 2005, 2006 e 2007.

Ao se estabelecer uma relação entre crescimento de matrícula e aumento do corpo docente, o setor público teve um aumento de $15,92 \%$ no primeiro elemento, enquanto cresceu $15,02 \%$ no segundo. A diferença entre os aumentos foi mínima, já que atingiu um patamar de 0,9 pontos, o que demonstra uma manutenção relativa na carga laboral.
Por outro lado, a mesma relação aplicada ao setor privado comprova um dado preocupante às IES dessa natureza, sobre as condições de trabalho dos seus professores. Se as matrículas cresceram na ordem de $81,41 \%$, neste segmento, e o professorado aumentou apenas $67,27 \%$, a diferença alcançada é de 14,14 pontos, muito superior ao índice público. Este tema 
pode ser aproveitado em futura pesquisa, que possa, adequadamente, se dedicar a tal problemática. Salienta-se que esta análise não será aprofundada no presente trabalho, por não ser pertinente ao objeto de estudo proposto.

\section{CONSIDERAÇÕES FINAIS}

Apesar de não ter se originado nos dias de hoje, a relação entre os segmentos público e privado, no âmbito do ensino superior, bem como a sua expansão, continua sendo tema atual. Desse modo, já se concluiu que "a defesa da contenção dos gastos públicos, em razão do aprofundamento da crise econômica, fora o elemento determinante para tornar a diversificação do sistema de educação superior uma realidade, no plano legal" (RIBEIRO, 2002, p. 12). Em outro trabalho, menciona-se que "públicoprivado na educação brasileira não é um acontecimento recente. O fato do Estado não assumir a educação como um serviço público, uma atividade prioritária, deixou-a vulnerável às pressões de grupos e interesses privados" (PINHEIRO, 1991, p. 46). Assim, muito se discutiu sobre "o papel do Estado na política de privatização desse nível de ensino" (SOUSA, 2003, p. 28-29).

Para Trigueiro (2000), a modernização da educação superior brasileira foi uma tarefa destinada ao segmento particular, tendo em vista o foco dado à sua expansão física e a qualidade do ensino, em relação ao pleiteado pelo mercado. Com isso, a rede privada seria, então, responsável pelos novos profissionais, com currículos mais atuais e perfis mais adequados às necessidades da sociedade. Não obstante o segmento público possuir quadro docente com melhores currículos, o mesmo autor (1999) concluiu que o setor particular tinha se tornado responsável pela dinâmica da educação superior como um todo, por desenvolver corretamente seus cursos (ante alterações favoráveis no currículo), por deter agilidade nas referidas correções curriculares e por flexibilizar suas práticas pedagógicas. Como conseqüência:

os melhores cursos são, cada vez
mais, os que possuem um bom
somatório de bons professores, bons
currículos e infra-estrutura
adequada, sobretudo em termos de
equipamentos de pesquisa.
[... uma demanda que as
universidades públicas, apesar dos
avanços conquistados, ainda não
têm conseguido suprir
(TRIGUEIRO, 1999, p. 62).

Nesse contexto, Sousa (2003) expõe que o setor particular tem demonstrado vigor no transcurso da expansão, por meio de elevados investimentos que têm fornecido lucros. Acrescenta, ainda, que a autonomia das universidades e dos centros universitários, 
em estender suas vagas e criar novos $\operatorname{cursos}^{12}$, tem fomentado os processos de expansão e concorrencial entre as IES particulares, sempre na procura de novos alunos.

A partir da análise estatística realizada, no período compreendido entre 1980 a 2006, as referidas conclusões continuam valendo para os dias atuais.

Portanto, ainda cabe ao seguimento privado formar a grande maioria dos discentes de graduação da educação superior brasileira. É público e notório que a iniciativa particular vem investindo, incessantemente, na educação.

Ressalta-se que o setor público também se expandiu, mas não como o particular, o que se justifica pela necessidade de investimentos moderados para a criação de estabelecimentos isolados, em comparação com universidades, centros universitários e faculdades integradas, bem como pelas políticas públicas implementadas no país, antes apresentadas. Assim, notou-se que a

12 Os centros universitários são IES pluricurriculares, caracterizadas pela extrema qualidade no ensino ofertado, mediante comprovação prévia nas avaliações do MEC, qualificação privilegiada dos docentes e pelas excelentes condições dos trabalhos acadêmicos fornecidos à sociedade. Possuem autonomia universitária para criar, organizar e extinguir cursos de ensino superior e programas de educação de mesmo nível, estendendo ou remanejando vagas nos que já existem, desde que o façam em sua sede institucional (arts. $1^{\circ}$ e $2^{\circ}$ Decreto $n^{\circ} 5.786 / 06$ ). Por sua vez, a previsão normativa da citada autonomia das universidades consta nos arts. 207 CR/88 e 53, inciso I, LDB. rede pública, com o passar dos anos, ocupou menor espaço na educação superior em geral, o que se tornou uma constante no sistema brasileiro, com raros períodos de exceções.

Do mesmo modo, as matrículas dos discentes aumentaram em todos os anos analisados, tanto no setor público quanto no privado, mas em menor grau no primeiro segmento. Comprova-se, então, que a ampliação do acesso ao ensino superior vem sendo uma responsabilidade das IES particulares. Tal afirmativa estava no plano teórico quando se apresentou a intenção do Poder Público (Governo e MEC), manifestada nos Pareceres CNE/CES no 293, de 06 de maio de 1998, e $\mathrm{n}^{\mathrm{o}}$ 05, de 07 de junho de 2000, de se ampliar o acesso da população à educação superior. As informações relativas às matrículas não deixam quaisquer dúvidas na efetivação das políticas públicas educacionais, planejadas desde 1998.

Novamente, demonstra-se que tanto na rede pública quanto na privada aumentaram o número de funções docentes em exercício no país, também em menor grau no setor público.

Em ambos os casos, segmentos público e particular, a expansão dos cargos docentes não acompanhou o aumento das matrículas, o que significa um incremento na carga de trabalho dos professores do ensino superior. Na rede pública, de 1999 
até 2006, a diferença entre os aumentos foi mínima, já que atingiu um patamar de 0,9 pontos, comprovando uma manutenção relativa no ônus laboral. Contrariamente, na rede privada, constata-se que a proporção de matrículas foi muito superior ao número de cargos docentes, demonstrando piores condições de trabalho no setor particular ou maior aproveitamento do professorado. No período de 1999 até 2006, as matrículas cresceram na ordem de $81,41 \%$, neste segmento, e os docentes aumentaram apenas $67,27 \%$, cuja diferença alcançada é de 14,14 pontos, muito superior ao índice público. Tal informação é um dado que merece maior investigação.

De qualquer modo, Sousa (2003) também salienta os dilemas do setor público, decorrentes da falta de um financiamento adequado "à sua complexidade e necessidade de expansão" (SOUSA, 2003, p. 33). Portanto, a ausência de recursos financeiros passa a ser uma preocupação, já que impossibilita o aumento de vagas para suprir as necessidades da sociedade, no que toca à educação superior, e dificulta a manutenção dos recursos humanos.

Os problemas da rede pública e o processo de expansão do segmento privado justificam as preocupações com relação aos instrumentos de avaliação permanente, principalmente quanto ao nexo causal que deve existir entre aumento de vagas da educação superior e manutenção do padrão de qualidade do ensino. Os mecanismos avaliativos, citados por Sousa (2003), como por exemplo, o Exame Nacional de Cursos (ENC) - provão, os procedimentos de autorização e reconhecimento de cursos por comissões de especialistas do INEP, mostraram-se alternativas viáveis, mas não englobam a IES como um todo, variando conforme a situação momentânea do estabelecimento durante a avaliação.

Cabe formular uma crítica à supramencionada opinião. Parece que houve um esquecimento referente ao procedimento de credenciamento de IES, que pode avaliar a instituição totalmente. De qualquer forma, os antigos procedimentos de autorização, reconhecimento de cursos e credenciamento de instituições foram, recentemente, reestruturados, para evoluírem e se adequarem à Lei $n^{\circ}$ 10.861/04, que introduziu novo método avaliativo do Sistema Nacional de Avaliação da Educação Superior (SINAES). A pretensão da Lei $n^{\circ}$ 10.861/04 foi instituir, de maneira permanente, uma avaliação das IES, dos cursos e do desempenho dos discentes de maneira integrada $\left(\operatorname{arts} .1^{\circ}\right.$ e $2^{\circ}$, inciso I, Lei do SINAES).

Por fim, em virtude de todos os problemas acima indicados, a ampliação de 
acesso às vagas de ensino superior torna-se imperativa. A necessidade de expansão da educação superior, no Brasil, fica cristalina quando se analisam os arts. 44 e 45 LDB que previram tipos diferenciados de instituições capazes de fornecer tal ensino. Assim e ante os pleitos da sociedade, considera-se positiva as novas modalidades de IES, quando se pretende a formação rápida de uma maior parcela da população brasileira, desde que se mantenha a qualidade do sistema de ensino superior.

\section{REFERÊNCIAS}

\section{ASSEMBLÉIA GERAL DAS NAÇÕES} UNIDAS. Resolução n ${ }^{\circ}$ 217-A (III), de 10 dez. 1948. Declaração Universal dos Direitos Humanos. Tradução oficial para o português por United Nations High Commissioner for Human Rights. 1948. Disponível em: $<$ http://www.comitepaz.org.br/download/D eclara\%C3\%A7\%C3\%A3o\%20Universal $\% 20$ dos\%20Direitos\%20Humanos.pdf $>$. Acesso em: 18/03/2008.

BARACHO, José Alfredo de Oliveira. $O$ Princípio de subsidiariedade: conceito e evolução. $3^{\text {a }}$ tiragem. Rio de Janeiro: Forense, 2000.98p.

BRASIL. Constituição (1988). Constituição da República Federativa do Brasil, 1988. Brasília: Senado Federal, Centro Gráfico, 1988. 292p.

BRASIL. Govêrno Costa e Silva. Reforma universitária: relatório do grupo de trabalho criado pelo Decreto $\mathrm{n}^{\circ}$ 62.937/68. [S.l.]: Gráfica do Colégio Pedro II, 1968. $128 \mathrm{p}$.
BRASIL. Lei no 4.024, de 20 dez. 1961. Fixa as Diretrizes e Bases da Educação Nacional. Diário Oficial, Brasília, 27 dez. 1961.

BRASIL. Lei no 5.540, de 28 nov. 1968. Fixa normas de organização e funcionamento do ensino superior e sua articulação com a escola média, e dá outras providências. Diário Oficial, Brasília, 23 nov. 1968 (retificada em 03 dez. 1968).

BRASIL. Lei no 9.394, de 20 dez. 1996. Lei de Diretrizes e Bases da Educação Nacional. Diário Oficial, Brasília, 23 dez. 1996.

BRASIL. Lei no 10.172, de 09 jan. 2001. Aprova o Plano Nacional de Educação e dá outras providências. Diário Oficial, Brasília, 10 jan. 2001.

BRASIL. Lei no 10.861, de 14 abr. 2004. Institui o Sistema Nacional de Avaliação da Educação Superior - SINAES - e dá outras providências. Diário Oficial, Brasília, 15 abr. 2004.

BRASIL. Lei $\mathrm{n}^{\circ}$ 11.096, de 13 jan. 2005. Institui o Programa Universidade para Todos - PROUNI, regula a atuação de entidades beneficentes de assistência social no ensino superior; altera a Lei $\mathrm{n}^{\circ} 10.891$, de 09 de julho de 2004, e dá outras providências. Diário Oficial, Brasília, 14 jan. 2005.

BRASIL. Ministério da Educação. Conselho Federal de Educação. Conselho de Ensino Superior. Parecer no 209, de 06 jun. 1967. Expansão do Ensino Superior no País. Documenta, Rio de Janeiro, $\mathrm{n}^{\mathrm{o}} 71$, p. 10-21, jun. 1967.

BRASIL. Ministério da Educação. Conselho Nacional de Educação. Câmara de Educação Superior. Parecer n ${ }^{\circ}$ 05, de 07 jun. 2000. Propõe a constituição de Comissão para analisar o tema "Políticas Públicas, Política Educacional e 
Fiscalização das Profissões". Documenta, Brasília, no 468, p. 436-451, set. 2000.

BRASIL. Ministério da Educação. Conselho Nacional de Educação. Câmara de Educação Superior. Parecer n ${ }^{\circ} 293$, de 06 mai. 1998. Associação Cultural Evolução/SP: autorização para funcionamento de curso Jurídico. Documenta, Brasília, no 440, p. 55-59, mai. 1998.

BRASIL. Ministério da Educação. Instituto Nacional de Estudos e Pesquisas Educacionais. Evolução do ensino superior: 1980-1998. Brasília: INEP, 1999. $71 \mathrm{p}$.

BRASIL. Ministério da Educação. Instituto Nacional de Estudos e Pesquisas Educacionais. Sinopse estatística do ensino superior: graduação 1999. Brasília: INEP, 2000. 234p.

BRASIL. Ministério da Educação. Instituto Nacional de Estudos e Pesquisas Educacionais. Sinopse estatística do ensino superior: 2000. Brasília: INEP, 2001. 400p.

BRASIL. Ministério da Educação. Instituto Nacional de Estudos e Pesquisas Educacionais. Sinopse estatística do ensino superior: 2001. Brasília: INEP, 2002.

Disponível em:

$<$ http://www.inep.gov.br/superior/censosu perior/sinopse/default.asp $>$. Acesso em: 12/04/2007.

BRASIL. Ministério da Educação. Instituto Nacional de Estudos e Pesquisas Educacionais. Sinopse estatística do ensino superior: 2002. Brasília: INEP, 2003.

Disponível em:

$<$ http://www.inep.gov.br/superior/censosu perior/sinopse/default.asp $>$. Acesso em: 12/04/2007.

BRASIL. Ministério da Educação. Instituto Nacional de Estudos e Pesquisas Educacionais. Sinopse estatística do ensino superior: 2003. Brasília: INEP, 2004.

Disponível em:

$<$ http://www.inep.gov.br/superior/censosu perior/sinopse/default.asp $>$. Acesso em: 12/04/2007.

BRASIL. Ministério da Educação. Instituto Nacional de Estudos e Pesquisas

Educacionais. Sinopse estatística do ensino superior: 2004. Brasília: INEP, 2005.

Disponível em:

$<$ http://www.inep.gov.br/superior/censosu perior/sinopse/default.asp $>$. Acesso em: 12/04/2007.

BRASIL. Ministério da Educação. Instituto Nacional de Estudos e Pesquisas

Educacionais. Sinopse estatística do ensino superior: 2005. Brasília: INEP, 2006.

Disponível em:

$<$ http://www.inep.gov.br/superior/censosu perior/sinopse/default.asp $>$. Acesso em: 12/04/2007.

BRASIL. Ministério da Educação. Instituto Nacional de Estudos e Pesquisas Educacionais. Sinopse estatística do ensino superior: 2006. Brasília: INEP, 2007.

Disponível em:

$<$ http://www.inep.gov.br/superior/censosu perior/sinopse/default.asp $>$. Acesso em: 01/08/2008

BRASIL. Ministério da Educação. Secretaria de Educação Superior. Enfrentar e vencer desafios: educação superior. Brasília: MEC; SESu, 2000. 39p.

BRASIL. Presidência da República. Câmara da Reforma do Estado. Plano diretor da reforma do aparelho do Estado. Brasília: Ministério da Administração Federal e da Reforma do Estado, 1995. 49p.

CUNHA, Luiz Antônio. A Universidade crítica: o ensino superior na República Populista. Rio de Janeiro: Francisco Alves, 1983. 264p 
CUNHA, Luiz Antônio. A Universidade reformanda: o golpe de 1964 e a modernização do ensino superior. Rio de Janeiro: Francisco Alves, 1988. 332p.

CUNHA, Luiz Antonio. A Universidade temporã: o ensino superior da colônia à era de Vargas. Rio de Janeiro: Civilização Brasileira; Edições UFC, 1980. 298p.

CUNHA, Luiz Antonio. Limites da escola particular na democratização do ensino. In: CUNHA, Luiz Antonio (Coord.). Escola pública, escola particular e a democratização do ensino. 2. ed. São Paulo: Cortez; Autores Associados, 1986. p. 119-130.

CURY, Carlos Roberto Jamil. Evolução da educação superior no Brasil: a participação do setor público e da iniciativa privada.

Revista Brasileira de Política e Administração da Educação, Brasília, v. 13, no 1, p. 39-69, jan./jun. 1997.

DURHAM, Eunice Ribeiro; SAMPAIO, Helena. O Ensino privado no Brasil. São Paulo: Universidade de São Paulo; NUPES, 1995. 18p. (Documento de Trabalho NUPES no $3 / 95$ )

DURHAM, Eunice Ribeiro. Uma Política para o ensino superior brasileiro: diagnóstico e proposta. São Paulo: Universidade de São Paulo; NUPES, 1998. 66p. (Documento de Trabalho NUPES ${ }^{\circ}$ 1/98)

FÁVERO, Maria de Lourdes de Albuquerque. Universidade \& poder: análise crítica/fundamentos históricos: 1930-45. Rio de Janeiro: Achiamé, 1980. 208p.

FERNANDES, Florestan. Universidade brasileira: reforma ou revolução? São Paulo: Alfa-Omega, 1975. 262p.

JAYME, Fernando G. Direitos humanos e sua efetivação pela corte interamericana de direitos humanos. Belo Horizonte: Del Rey, 2005. 208p.

MARTINS, Carlos Benedito de Campos. Ensino pago: um retrato sem retoques. São Paulo: Global Editora, 1981. 212p.

MARTINS, Carlos Benedito de Campos. O Novo ensino superior privado no Brasil (1964-1980). In: MARTINS, Carlos Benedito de Campos (Org.). Ensino superior brasileiro: transformações e perspectivas. São Paulo: Brasiliense, 1989. p. 11-48.

MARTINS, Carlos Benedito de Campos. O Público e o privado na educação superior brasileira nos anos 80. Cadernos CEDES: antropologia e educação interfaces do ensino e da pesquisa, Campinas, $\mathrm{n}^{\circ} 25, \mathrm{p}$. 63-74, 1991.

MINTO, Lalo Watanabe. As Reformas do ensino superior no Brasil: o público e o privado em questão. Campinas: Autores Associados, 2006. 320p.

PINHEIRO, Maria Francisca Sales. Publico e o privado na educação brasileira: um conflito na constituinte (1987-1988). 1991. 444f. Tese (Doutorado em Sociologia) - Universidade de Brasília.

RIBEIRO, Maria das Graças M. Educação superior brasileira: reforma e diversificação institucional. Bragança Paulista: EDUSF, 2002. 210p.

ROMANELLI, Otaíza de Oliveira. História da educação no Brasil (1930/1973). 29. ed. Petrópolis: Vozes, 2005. 272p.

SAMPAIO, Helena. Ensino superior no Brasil: o setor privado. São Paulo: Editora Hucitec; FAPESP, 2000. 408p.

SOUSA, José Vieira de. O Ensino superior privado no Distrito Federal: uma análise de sua recente expansão (1995-2001). 
2003. 279f. Tese (Doutorado em

Sociologia) - Universidade de Brasília.

TEIXEIRA, Anísio. Ensino superior no

Brasil: análise e interpretação de sua evolução até 1969. Rio de Janeiro: Editora

da Fundação Getúlio Vargas, 1989. 186p.

TRAMONTIN, Raulino; BRAGA, Ronald.

O Ensino superior particular no Brasil:

traços de um perfil. In: MENDES,

Candido; CASTRO, Cláudio de Moura

(Orgs.). Qualidade, expansão e

financiamento do ensino superior privado.

Rio de Janeiro: EDUCAM; ABM, 1984.

Cap. I.1, p. 19-50.

TRIGUEIRO, Michelangelo Giotto

Santoro. Ensino superior privado no

Brasil. Brasília: Paralelo 15; São Paulo:

Marco Zero, 2000. 128p.

TRIGUEIRO, Michelangelo Giotto

Santoro. Universidades públicas: desafios

e possibilidades no Brasil contemporâneo.

Brasília: Editora Universidade de Brasília, 1999. 183p.

UNESCO. Declaração Mundial sobre

Educação Superior no Século XXI: visão e ação. Paris: Conferência Mundial sobre

Ensino Superior, 1998. Disponível em:

$<$ http://www.interlegis.gov.br/processo_le

gislativo/copy_of_20020319150524/20030

620161930/20030623111830>. Acesso

em: 07/08/2008. 